\title{
The Vocation to Serve: Cornerstone of Health Care
}

\section{Ricardo A. González MD PhD DrSc}

Twenty-five hundred years ago, Hippocrates bequeathed a set of ethical precepts that emphasized the social transcendence of the practice of medicine and the profound commitment of physicians to serve patients and their families selflessly and with a pure heart.[1]

Traditionally, small-town medical practice facilitated spontaneous interpersonal relationships between family doctors and nurses and their patients. Later, however, centralization of health services in large medical complexes, an explosion of technology not always wisely deployed, litigiousness, tabloid journalism and commercialism in health service provision have created conditions that are, to say the least, less than propitious for optimal satisfaction on the part of patients and families. In my view, this has been accompanied by a dangerous devaluation of clinical skills, of medicine as a vocation, and by deterioration in the relationship of physicians and other health professionals with patients and their families.

These phenomena have dampened health care workers' capacity for compassion and made the sector increasingly bureaucratic, stressful and frustrating. First, for patients and families, because of dissatisfaction with services received; and second, for health workers themselves, because of the decreasing sense of health care as a vocation that in turn provides positive reinforcement from patient satisfaction and gratification from duty fulfilled. Although I see Cuba as one of the countries least affected by these tendencies, we are not entirely exempt.

What do I mean by a vocation? It is essentially a sense of being called to serve. Health care shares some characteristics with other service vocations-teachers, emergency responders, pastors and other religious workers, and even honest politicians and public servants: empathy, compassion, engagement and a wish to be of use.

From the time of extreme economic hardship in Cuba in the 1990s known as the Special Period, we began to see a gap between the material and human resources invested in health care services and patient satisfaction. Despite impressive achievements in ensuring universal free access to health care and in specific health indicators - such as very low infant mortality and infectious disease rates-levels of patient satisfaction fell short of expectations.[2]

Fifty years as a physician, psychiatrist, ethicist and professor of medicine allow me to pose several possible contributors to this phenomenon: high expectations on the part of a Cuban public well-educated and well-versed in health matters, but which can also lead to demands for unnecessary drugs or analyses; not infrequent complaints relating to some health care workers' interpersonal skills; insufficient importance accorded by some professionals to clinical and interviewing skills and to relationships with patients and family members; some professors' tendency to overemphasize knowledge and skills instruction the expense of educational objectives reinforcing values and attitudes; and the effects of reduced economic status on professionals and other health workers since the economic crisis of the 1990s. (While our health care providers are not subject to the litigious environment seen in some other countries, their lower standard of living, especially compared to the 1980 s when it was quite satisfactory, is a negative factor that should be overcome once conditions permit.)

By the same token, there are ways to confront these problems.

First, we need to broaden our definition of who is on the health care "team." Since a sense of vocation exists not only among health professionals and technicians but also, consciously or unconsciously, among auxiliary and administrative personnel in our institutions, our efforts to reinforce it should include them. We cannot overlook the potential impact on patients and families of the attitudes exhibited by other members of the health care team. For the patient, the orderly and the receptionist represent the hospital, just as much as the doctor or nurse!

Undergraduate and graduate education should take maximum advantage of the power of role modeling by professors in patient care. Witnessing someone with a true sense of vocation interact with a patient can have immeasurable and lasting influence on learners and affect their future behavior as professionals.

The recognition and reinforcement of a sense of vocation should be fundamental tasks for health care educators and managers, a primary factor in selection of candidates for the health professions as well as health workers in general.

Corollary to these suggestions is the need for better approaches to identifying and measuring a sense of vocation, and of course, better tools to more holistically assess patient satisfaction in all its dimensions.

I cannot overstress the urgency of these changes in health care training and services delivery, modifying the full range of factors in today's health care environment. Only by doing so can we reinstate the full humanistic relationship between the person who is seeking health or relief from suffering and those trained to promote health and to alleviate suffering - sworn to do so inspired by a profound calling to serve.

My hope is that with a broadened concept of the health care team and its appropriate vocational development, our health institutions may become veritable oases of respect, empathy, willingness to help, solidarity and engagement with patients and families, in which nothing human is alien. -1 -

1. Kottow M. Introducción a la bioética. Santiago de Chile: Editorial Universitaria; 1995. Spanish.

2. Chang M, Alemán ML, Cañizares MP, Ibarra AM. Satisfacción de los pacientes con la atención médica. Rev Cubana Med Gen Integr. 1999 [citado 27 abril 2012];15(5):541-7 Disponible en: http://scielo.sld.cu/scielo.php?script=sci _arttext\&pid=S0864 -21251999000500009\&Ing=es\&nrm=iso\&tlng=es. Spanish.

Submitted: January 23, 2012

Approved for publication: July 23, 2012

Disclosures: None 